\title{
Web Application to Build Information System of National Seminar Alerts in Indonesia
}

\author{
Erlin, Khusaeri Andesa, Agustin \\ Department of Informatics Engineering, STMIK Amik Riau, Indonesia
}

\begin{tabular}{l}
\hline \hline Article Info \\
\hline Article history: \\
Received Sep 25, 2017 \\
Revised Jan 8, 2018 \\
Accepted Aug 27, 2018
\end{tabular}

\section{Keyword:}

Information system

Seminar alerts

Web application

\begin{abstract}
The output of research in the form of a proceeding published through a national seminar or an international conference has become a routine activity performed by lecturers as a researcher. The escalating atmosphere of disseminating the results of a study is directly proportional to the increasing number of universities, associations, or non-educational institutions organizing either a national seminar or an international conference. Each seminar organizer posts their seminar relevant information through official sites released by each organizer. However, to date, there has never been storage that can compile all the information pertinent to all national seminars held in Indonesia. This situation has resulted in the search done by search engines such as Google, Yahoo Search, Bing and others have not been efficient nor effective. Design of a web-based national seminar alert system is built to address this issue. This information system can display all the seminars held in Indonesia in the current year in storage and can be broken down based on the choices of topic, location, and date. Other additional facilities are that the application can send email messages to the application users as an early warning on the upcoming national seminar. Researchers can track each existing national seminar and always up-to-date on the most current national seminar.
\end{abstract}

Copyright (C) 2018 Institute of Advanced Engineering and Science. All rights reserved.

\section{Corresponding Author:}

Erlin,

Department of Informatics Engineering,

STMIK Amik Riau,

Jalan Purwodadi Indah, Km. 10, Panam-Pekanbaru, Riau, Indonesia.

Email: erlin@stmik-amik-riau.ac.id

\section{INTRODUCTION}

Research activity is one of the three pillars of higher education that must be conducted by a lecturer. The Ministry of Research, Technology and Higher Education (Kemeristekdikti), Republic of Indonesia, has annually and regularly offered grant programs for research and community services to all lecturers under Kemenristekdikti. To improve academician's scientific publication quality and quantity, a publication is obliged as it is regulated under The Ministry of Research, Technology and Higher Education regulation (Permenristekdikti) No. 44 of 2015 on the Higher Education National Standard [1]. Scientific publication and presenter at a national seminar or an international conference is the type of output that becomes annual achievement for each research scheme funded by Kemenristekdikti. Then increased atmosphere for the dissemination of research result through a national seminar or international conference is directly proportional with the increase of the number of universities, associations, or non-educational institutions organizing a national seminar or international conference. Each seminar organizer posts their seminar-related information through official sites released by each organizer.

Based on the lecturer's data on the higher education database of Kemenristekdikti, 39,392 lecturers are still in the level of Bachelor Degree (14.32\%) from the total of 274,988 lecturers in Indonesia. The number of lecturers with a Master's Degree is 179,087 (65.13\%), and lecturers with Ph.D. are 34,471 
(12.54\%), while the rest are 22,038 (8,01\%) with a D4 (Associate Degree), Sp-1, Professionals, and nondegree [2]. Based on the percentage, the largest composition of lecturers in Indonesia is both having their Master's or Bachelor's Degree (79.45\%) whose majority make use of national seminar as the media to disseminate their research result.

In disseminating their research, researchers/presenters will decide when, where, and how they will communicate their research result. Based on the interview with several lecturers as researchers, most of them input the keywords of national seminar followed by the keywords on the paper's topic on a search engine when they are looking the information on a national seminar they are interested in. The next step is these researchers will then briefly review and click on a seminar link out of all the seminar options displayed by the search engine. If the accessed seminar is not appropriate with the time and location, then these researchers/presenters will refresh search process until they find the seminar they expected.

Design of a web-based national seminar information system to be built to address this issue. Studying the web-based information can serve various purposes. A number of researchers have been proposed some studies on a web application and information systems. For example, Hossard et al.,[3] have been studied a web application to facilitate crop model comparison in ensemble studies. The application is freely available and ready-to-use for understanding single model responses and identifying groups of crop models sharing similar behavior. Carafa et al.,[4] have been created the design principles, strategies, and architecture of SHINE, a web-based application for determining the maximum horizontal compressive stress orientation. The other researchers [5] have been designed SAUCE, a web application for interactive teaching and learning of parallel programming. Lewis and Reicher [6] have been proved that web applications for patient communication is good medicine and serves the enlightened economic interests of imaging professionals as well. Furthermore, Al-Othman et al.,[7] have been presented an adaptive educational web application for engineering students that focuses on personalized learning in large college classes by enabling proactive and continuous student engagement.

Research in the field of information systems has also experienced very rapid development since information systems play an important role in modern organizations. Some researches seriously discuss this information system from various aspects. A'ang Subiyakto et al.,[8] have been conducted a survey to measure the user satisfaction perspectives of the information system projects. The results revealed that, besides the system and service qualities of the endogenous variables, the institutional contexts are also indirectly influenced the variables. Furthermore, [9] have been introduced and proposed an approach in goaloriented requirements elicitation process that uses Key Performance Indicators, in information system enhancement process. They claim that IT goals and KPIs are more easily identified in the enhancement process rather than through the development of a brand new information system. The other researchers have been examined the sequential revisions of an information system project framework across the research model development. The authors were succeeding to present an interrelation between the framework and the examined model within a coherent representation [10]. Hence, this research is focused on building web application of information system of national seminar alerts in Indonesia.

This national seminar alert system will cover all the information on a national seminar organized in Indonesia for the current and the following years and can be made more specific based on location/region of the seminar. Then, this information system is also designed to be able to display national seminars based on the research discipline/topic to make it easier for the presenters to identify the kind of seminar to register to along with the time and location. Other developed facilities are that the information system can send email messages to the users as an early warning on their registered national seminar. In this research, web technology will be implemented on the seminar alert information system. As a result, the information system can be accessed anytime and anywhere using an internet browser. Researchers can track all existing national seminar and always up-to-date with the most current national seminar.

\section{THEORETICAL BACKGROUND}

\subsection{National Seminar}

The national seminar is a forum for all researchers around a country (not always a lecturer/academician) to present and discuss their research. Along with an academic journal or scientific journal, a national seminar provides an essential channel for information exchange between researchers. A seminar is typically comprised of numerous presentation. A presentation is brief around 10-20 minutes and then followed by a discussion. The result of research can be bound in a written form as an academic manuscript and published as a seminar proceeding.

A seminar normally includes keynote speakers usually academicians, although it can also come from non-academician. A keynote speaker delivers a general lecture for $1-1 \frac{1}{2}$ hours. A national seminar is 
ordinarily attended by several keynote speakers who present one after another. Aside from presentation, a seminar also includes a panel discussion or a roundtable related to numerous research issues.

A national seminar is usually arranged on one track or several tracks consisting of several parallel sessions with presenters presenting their paper in different rooms at the same time. A national seminar is sometimes followed by social activities or entertainment such as tourist attractions, which become a part of the seminar's program. This national seminar is usually organized by a scientific community or a group of researchers for a common interest. A national seminar can sometimes be hosted by a professional seminar organizer.

This forum is usually announced through a "call for paper (cpf)” on a poster/pamphlet/brochure sent to potential presenters, which contains an explanation on how to submit the manuscript. CPF mentions the theme of the seminar, the list of topics and the formalities of the forum, such as manuscript format, where to send, and submission due date. The seminar's poster is usually sent through email, mailing list, or specific online service.

\subsection{Web Application}

A web application or commonly called as webapps is an application accessed through the web browser as the client [11]. A client is a word widely applied in the discussion of client-server application. A client can become an application used to input. A client can be said as an application used to input information, while a server is an application used to store data. The web application consists of the following three primary layers: (a) Presentation layer, the first layer located on the side of the user and commonly comprising of a web browser; (b) Application layer, the second layer consisting of the technology resulting in a more dynamic content, like Java Server Pages (JSP) or Active Server Pages (ASP); (c) Storage layer, the third layer of databases used to store displayed information.

The work process of the web application through the three primary layers is presented in Figure 1. When typing the web address in the browser, the browser goes to the DNS server and searches for the actual server address on which the website is located. The browser sends an HTTP request message to the server, requesting a copy of the site to be sent to the client. This message, and all data transmitted via an internet connection using TCP / IP between client and server. If the server agrees to the client's request, the client can go to the destination website, and then start sending the website file to the browser as small parts called packet data. The browser combines data packets into an entire web and displays them.

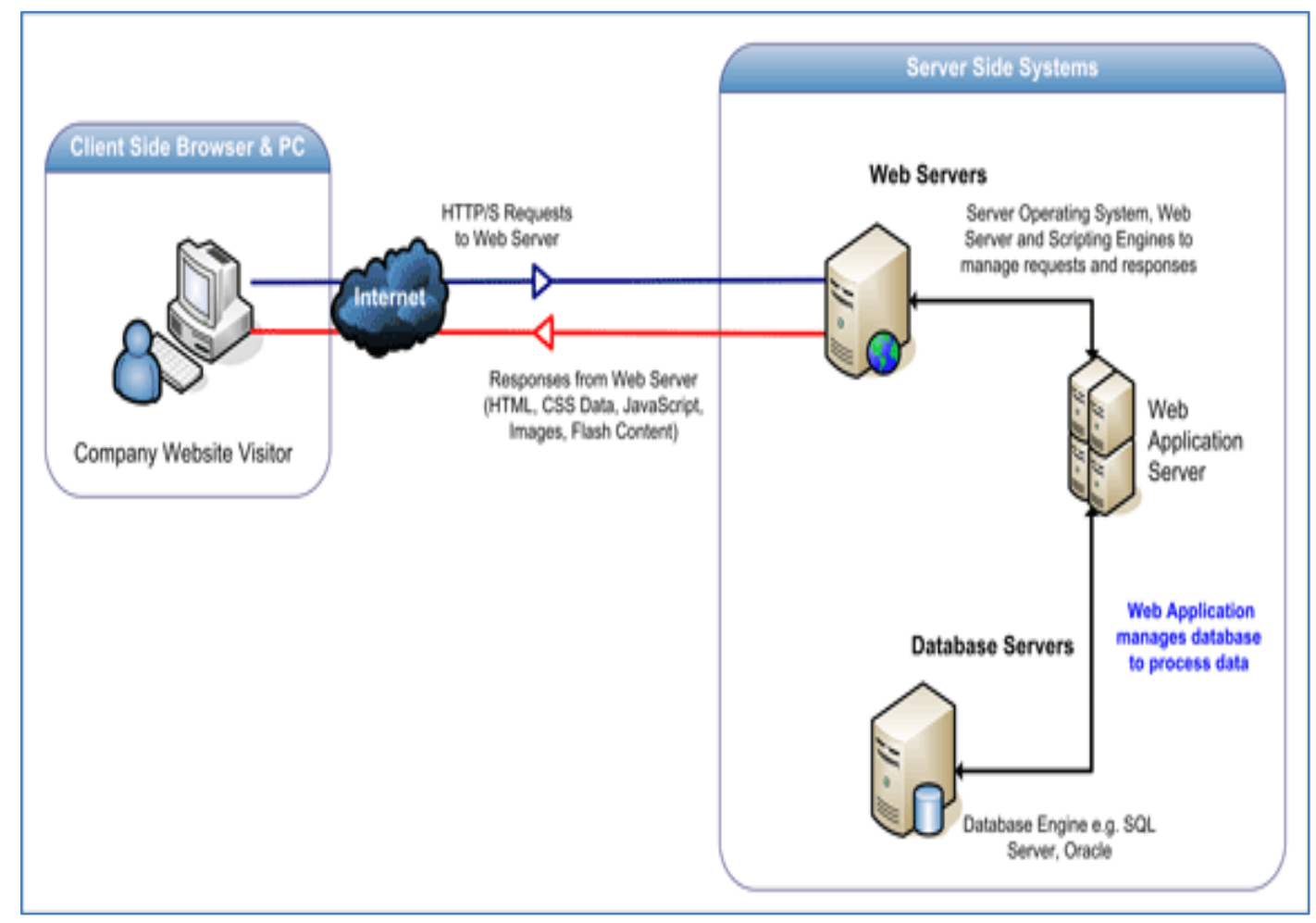

Figure 1. Three primary layers of web application [12] 


\section{ANALYSIS AND DESIGN}

\subsection{Requirement Specification}

System requirement is displayed on the use case diagram above, which shows the relationships between actors and system. Based on use case diagram in Figure 2, there are three actors involved in the system, which are administrator, organizer, and user. The administrator is tasked to organize the topic and type of the seminar, manage provincial data, organizer data, and to validate registration. The organizer is tasked to oversee seminar's data. Besides, the organizer and the user can perform a seminar search based on particular characteristics, to see the list of the whole seminar, and to see next seminars. The strengths of the users (academician, practitioners, scholars, and students) are that they can register their email address to obtain information on current news on upcoming seminar related to the focus of their research.

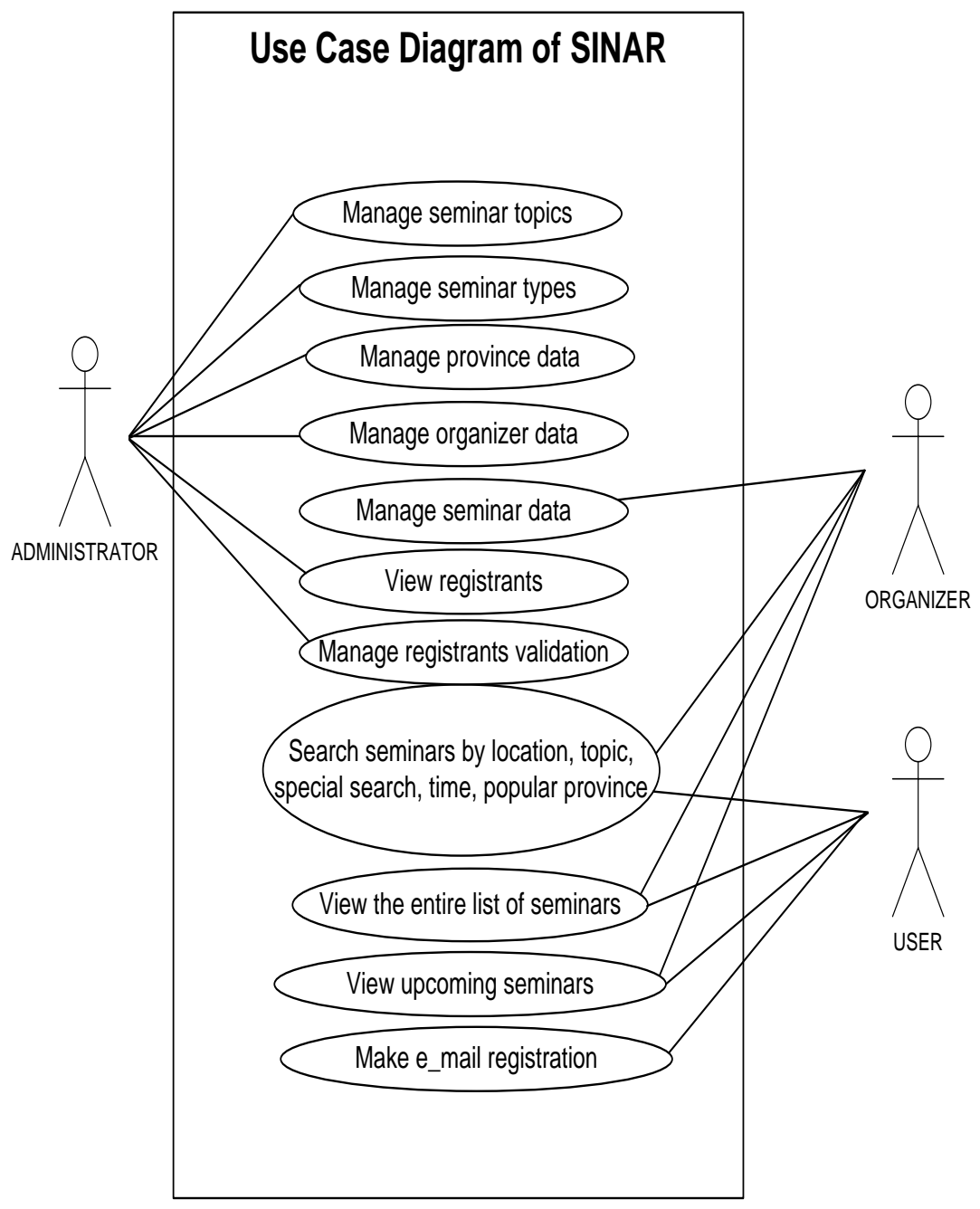

Figure 2. Use case diagram

\subsection{Database Design}

The database used in this application is SQL. The logic of this database is stored in the form of javascript and SQL file. SQL database can be accessed using application that has been stored in a server. The database design is shown in Figure 3 which displays the relationships between one table and another in the form of interconnectedness between the primary key and foreign key of each table.

From that figure we can see the relation between eight tables; event, event_type, island, province, event_topic, sub_event_topic, follow and register. Three other tables are contact, user and homex were created with the aim to make the website dynamic, so easy to modify and changes the data and information related to the front page, master table, contact info and reset password. 


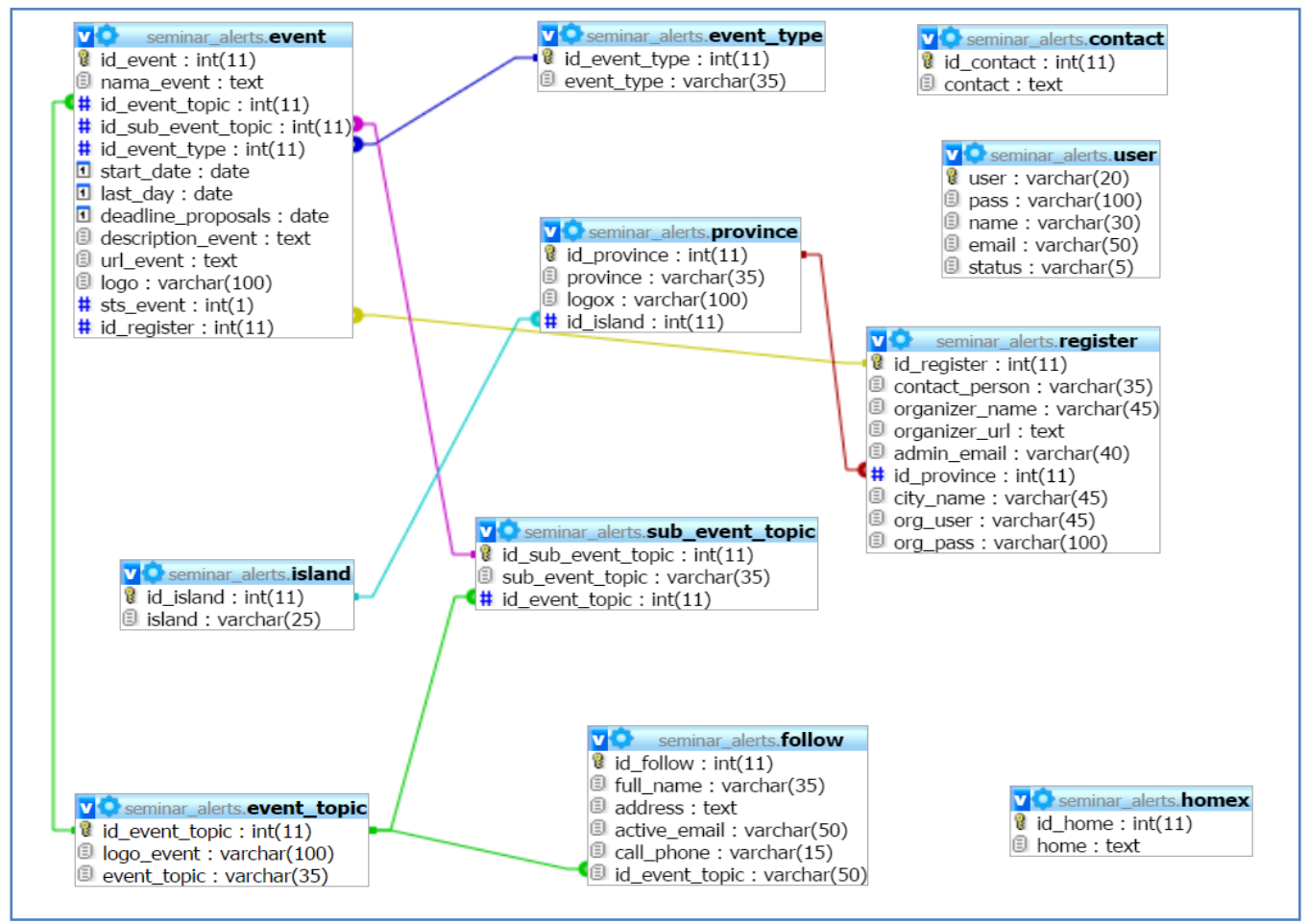

Figure 3. Database design

\section{RESULTS AND DISCUSSION}

\subsection{Main Menu Page}

The display for the home page of the seminar alert information system is designed by implementing a user-friendly concept so that it can be easily used by the users. There are three actors who have differing access rights. The administrator can perform the processes of addition, deletion, editing, validating, monitoring, and controlling the whole system. National seminar organizer can perform seminar data addition, deletion, editing, and national seminar monitoring that have been inputted to the system. The user can see all national seminar data that have been registered by the organizer and can register to obtain news update on the most current seminar relevant to the concentration of each user. Figure 4 below is the home page for all three actors using the system.

The home page also provides seminar organizer's login facility, register's menu for new organizers, and add seminars for existing organizer. Besides, user's menu is also offered for those who are interested in receiving regular information on national seminars related to their concentration through the 'follow' menu. The home display is also able to show the popular province to become the host of national seminar based on the seminar location for each region/province.

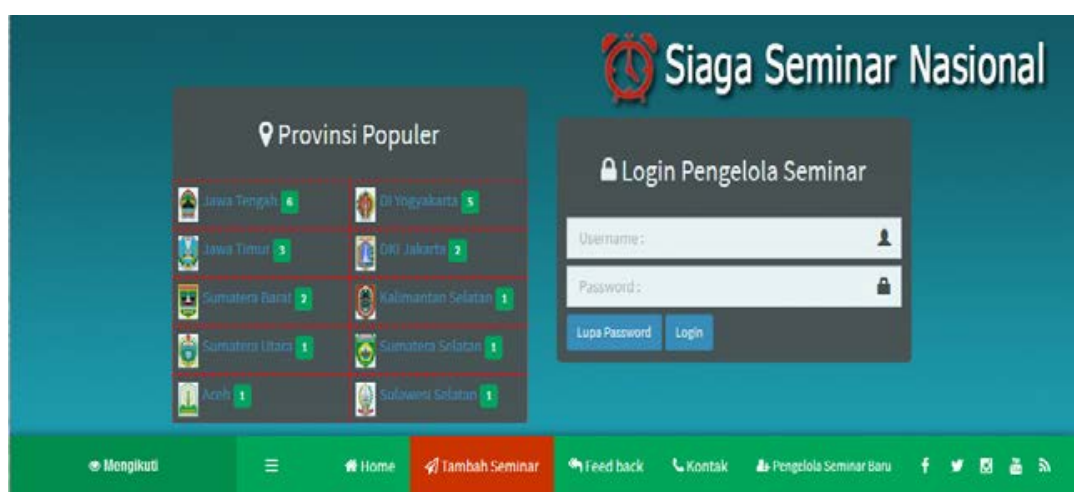

\begin{tabular}{|c|c|}
\hline \multicolumn{2}{|c|}{ Legend } \\
\hline Sangeminar Nasond & $\begin{array}{l}\text { National seminar } \\
\text { alert }\end{array}$ \\
\hline P Provinsis Populer & Populer province \\
\hline Login Pengeglolas Seminur & Organizer's login \\
\hline Lupa Passonod & Forget password \\
\hline Ilengktot & $\begin{array}{l}\text { Follow the new } \\
\text { seminar }\end{array}$ \\
\hline Arambahserinar & Addnew seminar \\
\hline Pengebla Semingy Baru & $\begin{array}{l}\text { Organizer for new } \\
\text { seminar }\end{array}$ \\
\hline
\end{tabular}

Figure 4. Home page display 


\subsection{Organizer's Menu}

Each organizer has to first register from the menu new seminar organizer, which consists of primary data on seminar organizer. The main data comprises of contact person, organization name, national seminar url, national seminar admin's email, province of the venue, city, username, and password of the organizer admin.

The next step for the organizer is to input data related to the registered national seminar as shown in Figure 5. The inputted data is nama seminar (the national seminar's name), topik seminar (seminar topic), sub topik seminar (sub-seminar topic), tipe seminar (seminar type), tanggal mulai seminar (seminar start date), tanggal selesai seminar (last day of seminar), tanggal deadline abstrak/proposal (deadline for abstracts/proposals), and deskripsi singkat seminar (the short description of seminar).

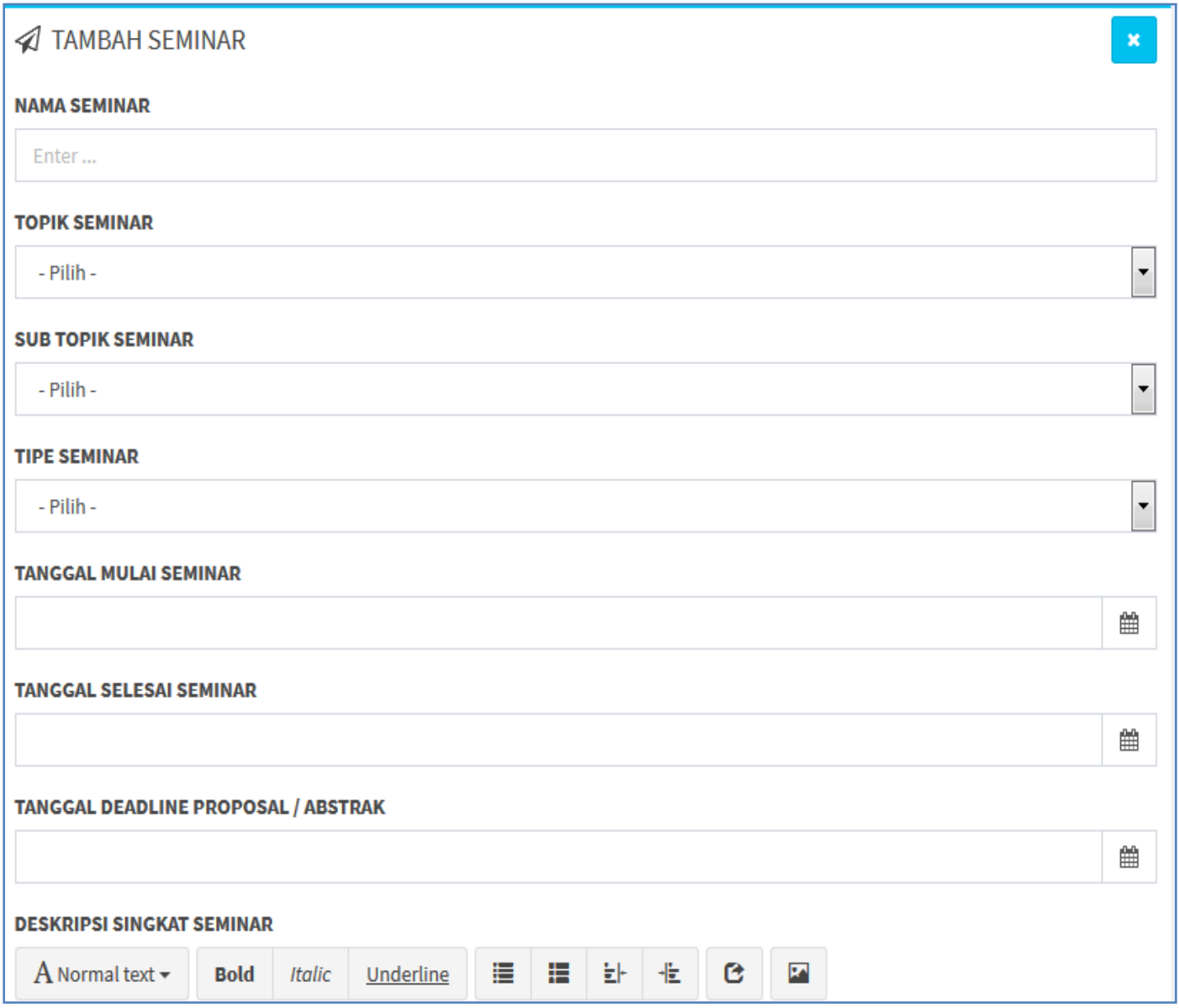

Figure 5. Input menu to add seminar

\subsection{User's Menu}

The users (academician, practitioner, scholar, student and others) can visit the national seminar alert page to obtain information on the national seminars in Indonesia that can be filtered based on topics, location, or the time of seminar commencement. National seminar alert allows for the user to receive free email notification on a seminar that can participate according to the topics and locations.

Figure 6 shows the menu that can be used by the user to filter the result of national seminar search based on topics. There are 10 (ten) topics that can become the primary concentrations, such as Bisnis dan Ekonomi (Business and Economics), Fisika dan Ilmu Kehidupan (Physics and Life Sciences), Hukum (Law), Ilmu Hewan (Zoology), Ilmu Sosial dan Humaniora (Social Studies and Humanities), Interdisipliner (Interdisciplinary), Kesehatan dan Kedokteran (Health and Medicine), Matematika dan Statistik (Mathematics and Statistics), Pendidikan (Education), and Rekayasa dan Teknologi (Engineering and Technology). 


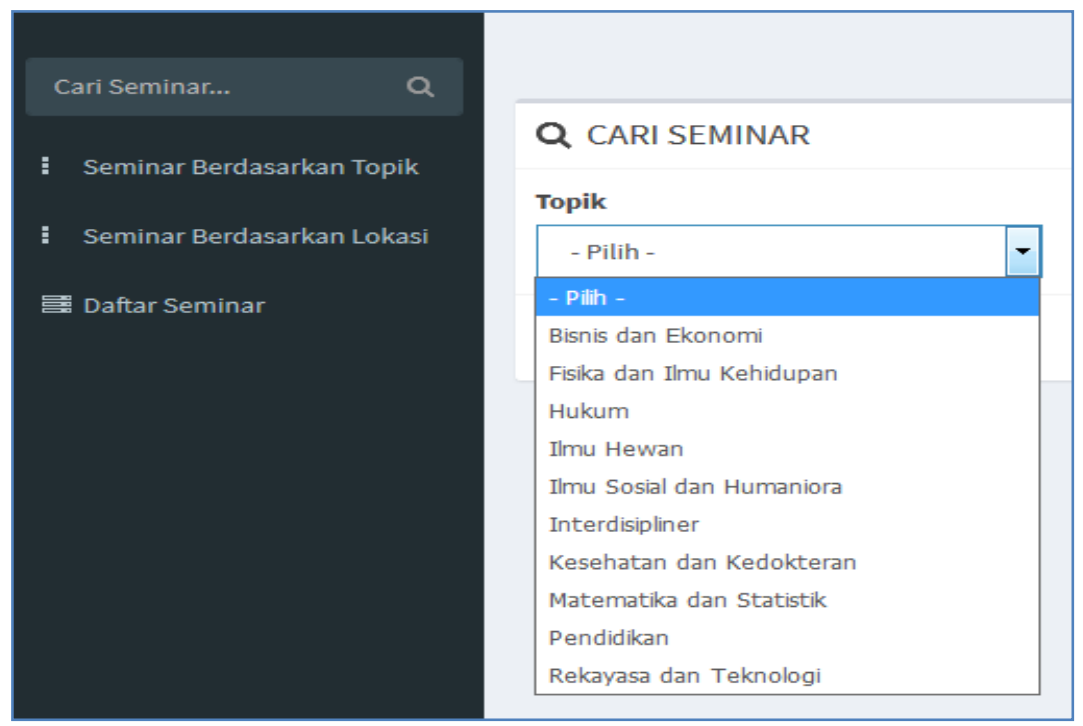

Figure 6. Seminar search based on topics

The search result of national seminar based on a topic is shown in Figure 7, filtered based on the topic of Physics and Life Science. The search result shows 5 (five) national seminars based on those topics which seminar's location is located in several regions, such as Seminar Nasional Kimia UNY 2017 (National Seminar of Chemistry, Yogyakarta State University, 2017), held in Yogyakarta on October 14, 2017, Seminar Nasional Kebumian 2017 (National Seminar of Earth, 2017), held still in the city of Yogyakarta on September 13, 2017, Seminar Nasional Pendidikan Kimia 2017 (National Seminar of Chemistry Education, 2017), held in Kalimantan Selatan on September 16, 2017, Seminar Nasional Pendidikan Biologi dan Saintek II 2017 (National Seminar of Biology Education and Science and Technology, 2017), held in Jawa Tengah on Mei 20, 2017, and Seminar Nasional Biotik 2017 (National Seminar of Living Things, 2017), held in Aceh on Mei 3, 2017. From the list of seminars that are displayed, it allows users to define national seminars to be followed based on topics that serve as the basis of the search.

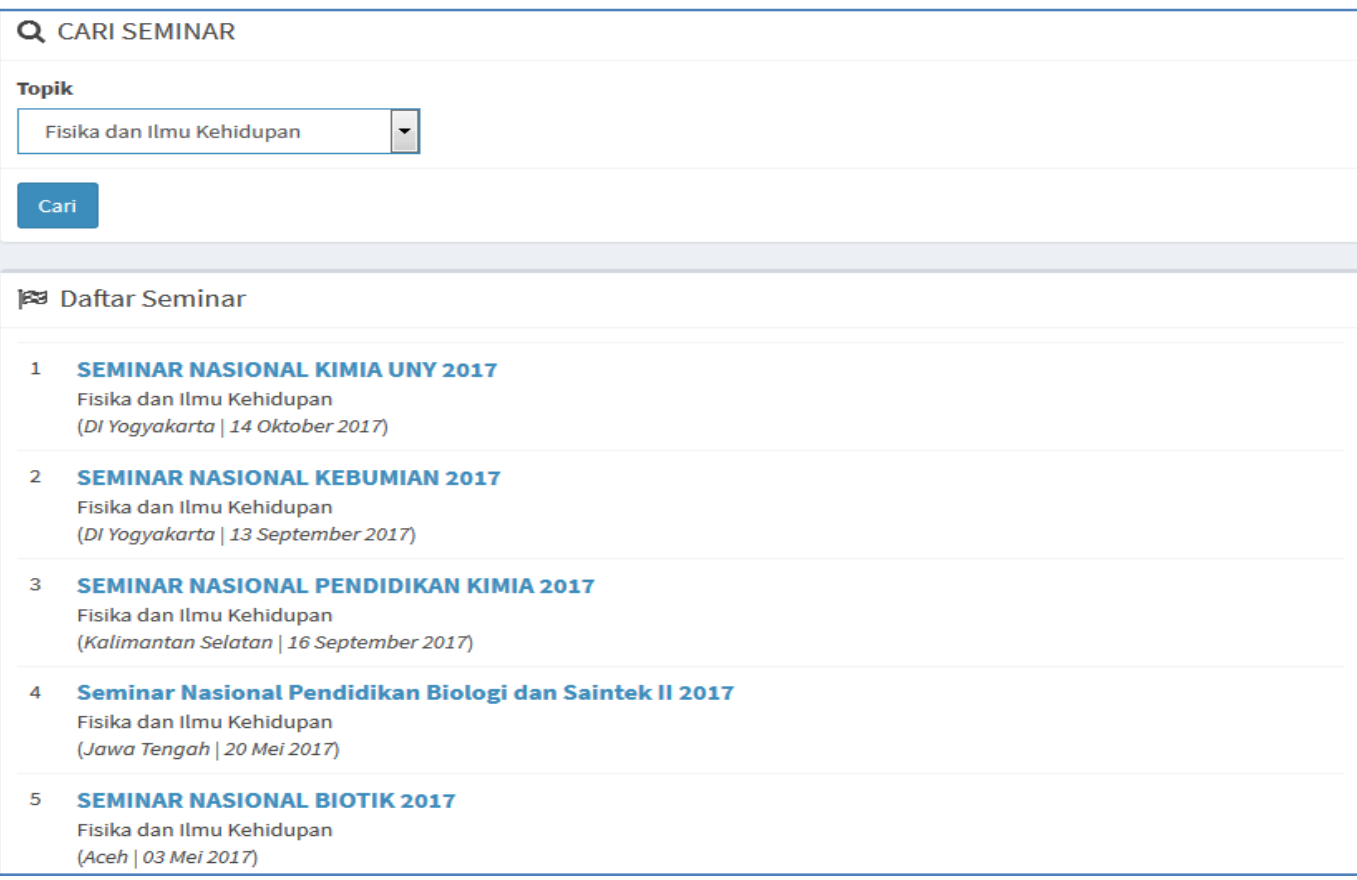

Figure 7. Search result of national seminar based on topics 
National seminar search based on interested region/location also becomes the strength of this application as shown in Figure 8. The user can filter the national seminar based on wanted location by clicking on the search seminar menu. There are 34 (thirty-four) provinces in Indonesia that may be hosting national seminars, for example, DKI Jakarta, Sulawesi Tenggara, Aceh, Bali, Bangka Belitung, Banten, Bengkulu, DI Yogyakarta, and so forth. All national seminar listings in thirty-four provinces can be traced at this system. Only by clicking on the destination province, then the system will display all national seminars held in the region concerned.
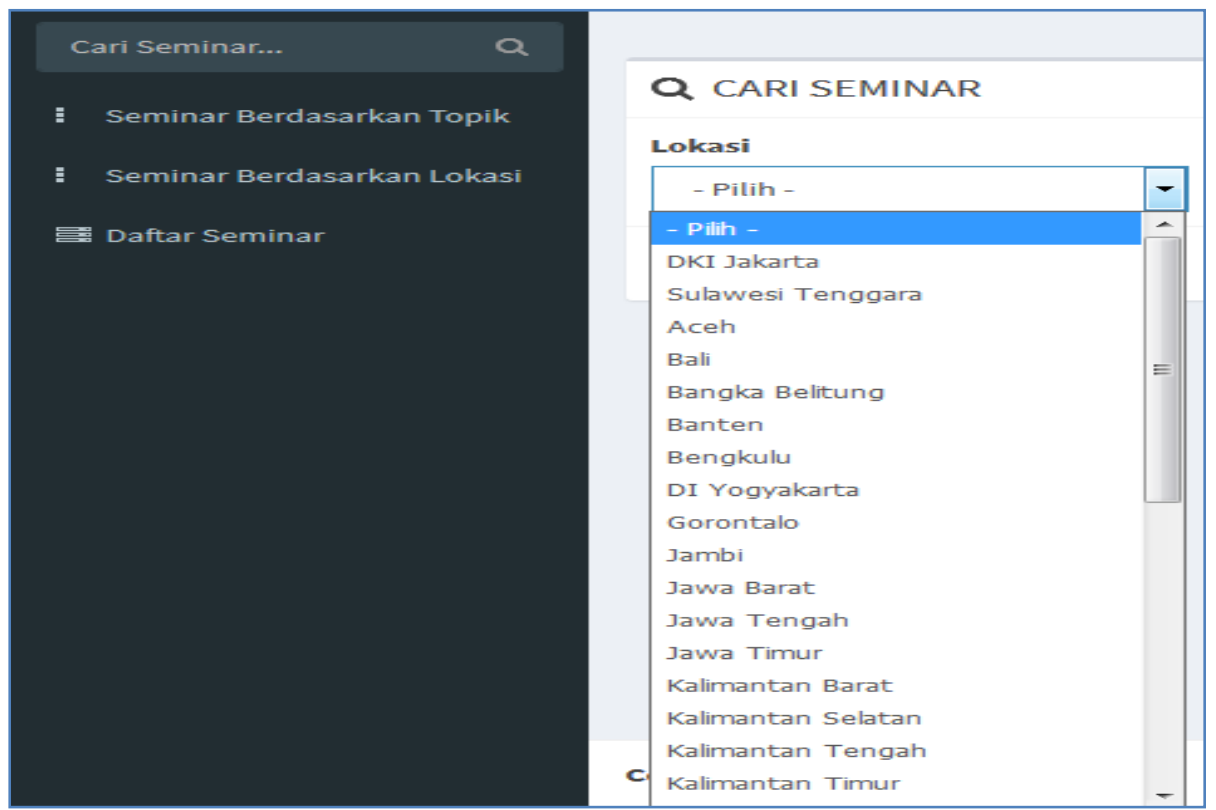

Figure 8. National seminar search based on location

Figure 9 below shows the ability of the system to visually display the number of seminars held in each province in Indonesia with pay attention to the numbers that exist after the name of the province. From here, users can see, the number of national seminars held in each province.

Seminar Nasional Per :

Figure 9. National seminar per province 
Another specialty for this information system of national seminar alert in Indonesia is its ability to display more detailed searches such as filter based on category/topic, location, keyword, month and year so that it can provide a more specific search result. Figure 10 below shows a more detailed national seminar search menu.

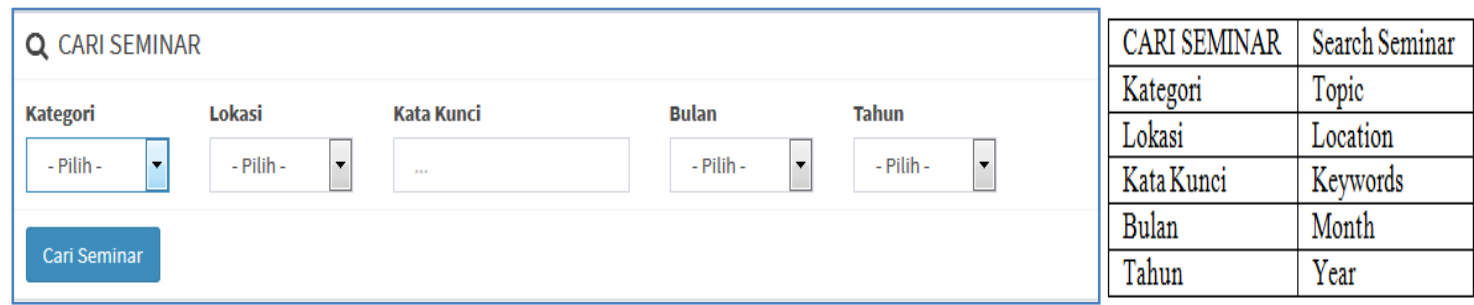

Figure 10. Seminar search based on category, location, keywords, month and year

A validated national seminar will be displayed on the home page on the upcoming seminar list as shown in Figure 11. A list of upcoming seminars can be used to view the seminars that be held in the future. In the system, there will be 5 (five) upcoming seminars; Seminar Nasional Teknologi Dan Rekayasa Informasi 2017 (National Seminar on Technology and Information Engineering 2017), Seminar Nasional Matematika XI 2017 (National Seminar of Mathematics XI 2017), Seminar Nasional Kimia UNY 2017 (National Seminar of Chemistry, UNY 2017), Seminar Nasional Supply Chain dan Logistik Indonesia 2017 (National Seminar of Supply Chain and Indonesia Logistic 2017) and Seminar Nasional Jelajah Arsitektur Tradisional 2017 (National Seminar of Cruising Traditional Architecture 2017).

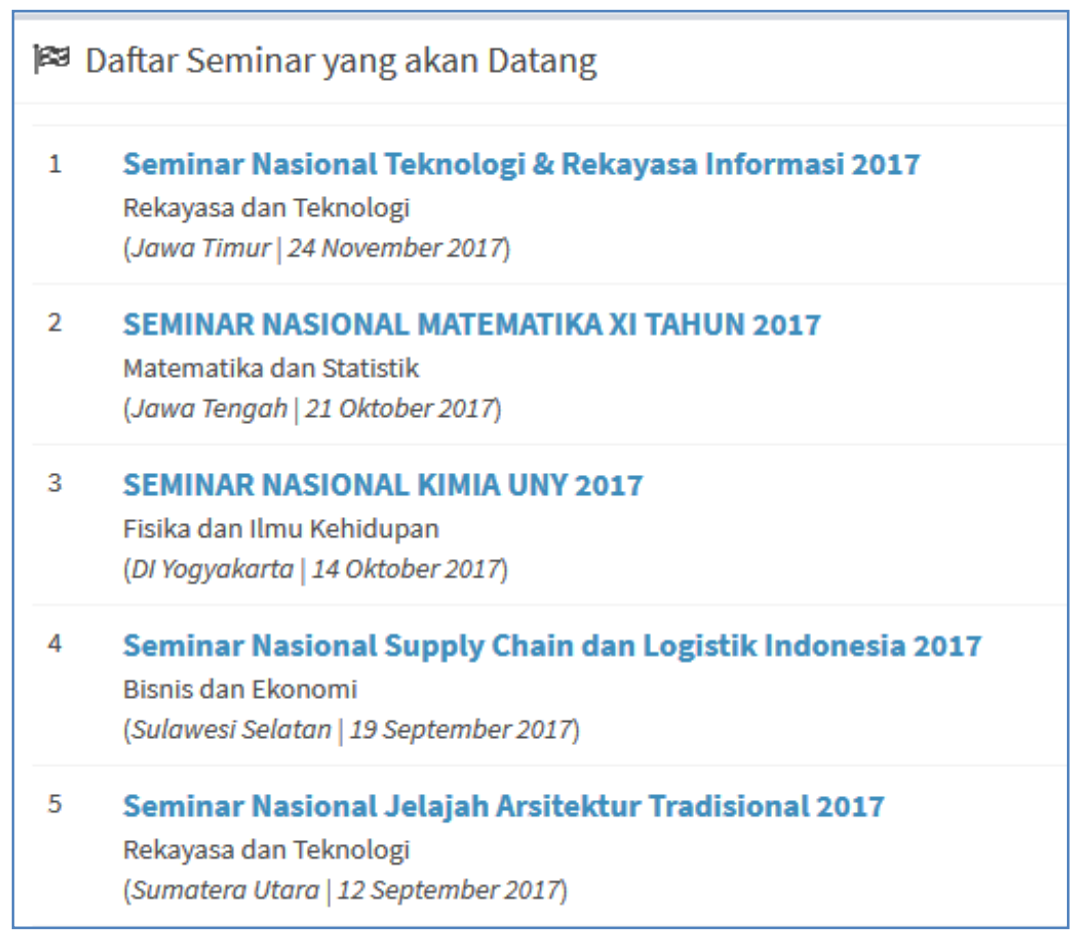

Figure 11. Upcoming seminar

\section{CONCLUSIONS}

Design of web-based information system of Indonesian national seminar alert has been built to overcome the issue of user's (academician, practitioners, scholars, students and another user) difficulty to search for information on a national seminar relevant to the scope/research topic of each user. This 
information system of seminar alert in Indonesia will cover the complete information on the national seminars organized in Indonesia in concurrent and following years and can be made into more specifically detailed based on location/region of the seminar. Although it can also be used by the user as the primary objective of this research, the system can also be used by the national seminar organizer to share clear and complete information for the potential user. National seminar alert also allows for the user to receive free email notification seminars that participated according to the topic and location options. Researchers can track each existing national seminar and always be up-to-date with the most current news on the national seminar.

\section{ACKNOWLEDGEMENTS}

The authors thank the Ministry of Research, Technology and Higher Education (Kemenristekdikti) Indonesia, for funding this research through the scheme of Penelitian Strategis Nasional (under contract No. 031/Kontrak-Peneliti/K10/KM/2017). STMIK Amik Riau campus and all persons involved in this researches are also acknowledged.

\section{REFERENCES}

[1] The Ministry of Research, Technology and Higher Education, "Regulation of The Ministry of Research, Technology and Higher Education (Permenristekdikti) No. 44 of 2015 on the Higher Education National Standard,” pp. 1-58, 2015.

[2] The Ministry of Research, Technology and Higher Education, “Higher Education Database,” Retrieved October 10, 2017, url https://forlap.ristekdikti.go.id/

[3] L. Hossard, et al., "A Web Application to Facilitate Crop Model Comparison in Ensemble Studies,” Journal of Environmental Modelling \& Software, vol. 97, pp. 259-270, 2017.

[4] M. M. C. Carafa, et al.,"SHINE: Web Application for Determining The Horizontal Stress Orientation,” Journal of Computers \& Geosciences, vol. 74, pp. 39-49, 2015.

[5] C. Hundt, et al.,"SAUCE: A Web Application for Interactive Teaching and Learning of Parallel Programming," Journal of Parallel and Distributed Computing," Article in Press.

[6] K. Lewis and M. A. Reicher,"Web Application for Patient Communication,”Journal of The American College of Radiology, vol. 13, no. 12, pp. 1603-1607, 2016.

[7] M. A. Al-Othman, et al., “An Adaptive Educational Web Application for Engineering Students,” IEEE Access, vol.5, pp. 359-365, 2017.

[8] A. Subiyakto, et al.,"The User Satisfaction Prespective of The Information System Projects," Indonesian Journal of Electrical Engineering and Computer Science, vol. 4, no. 1, pp215-223, 2016.

[9] F. Adikara, et al.,"Organization Goal-Oriented Requirements Elicitation Process to Enhance Information System," International Journal of electrical and Computer Engineering, vol. 6, no. 6, pp 3188-3195, 2016.

[10] S. J. Putra, et al.,"A Coherent Framework for Understanding the Success of an Information System Project," Journal of TELKOMNIKA (Telecommunication, Computing, Electronics and Control), vol. 14, no. 2, pp. 302-308, 2016.

[11] N. Daniel,"Improve your Understanding of Web Applications: What is a Web Applications?,” Retrieved November 27, 2017, url: https://www.lifewire.com/what-is-a -web-application-3486637

[12] Acunetix,"Web Applications: What Are They? What of Them?”, Retrieved November 30, 2017, url: http://www.acunetix.com/websitesecurity/web-applications/ 


\section{BIOGRAPHIES OF AUTHORS}
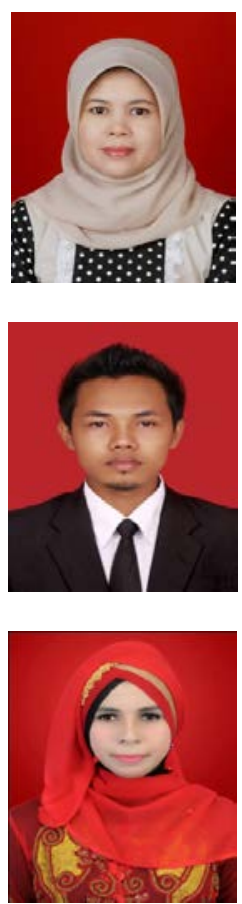

Erlin received the Ph.D. degree in computer science from the Universiti Teknologi Malaysia (UTM) in 2011. She is currently an Associate Professor of Informatics Engineering with STMIK Amik Riau. She conducted research in the domain of social network, computational intelligence, intelligence system, content analysis, web application and mobile technology. She participated in several research projects funded by The Ministry of Research, Technology and Higher Education, The Republic of Indonesia. She has authored several conference and journal papers, and currently she is a senior lecturer at the STMIK Amik Riau college, Indonesia.

Khusaeri Andesa was born in Pekaka, Indonesia, in 1989. He received the Bachelor of Computer Science degree from STMIK Amik Riau, in 2011, and the Master of Computer Science degree from Universitas Putra Indonesia YPTK Padang, in 2015. In 2012, he joined the Department of Informatics Engineering, STMIK Amik Riau as an assistant lecturer and in 2015 as a permanent lecturer. His current research interests include web application, mobile technology, and data mining. He has been working on several projects related to information technology to government and private institutions.

Agustin was born in Padang, Indonesia, in 1988. She received the Bachelor of Computer Science degree from STMIK Amik Riau, in 2013, and the Master of Computer Science degree from Universitas Putra Indonesia YPTK Padang, in 2016. Since then, she has been with the Departement of Informatics Engineering, STMIK Amik Riau, where she is currently an instructor. Her main areas of research interest are artificial intelligence, information systems and, web application. 